\title{
Extremely Bent Cyanide Coordination at a Preorganized Dinickel Site and Assembly of a Starlike Nonanuclear Complex from the Constrained Dinickel Building Blocks
}

\author{
Franc Meyer, ${ }^{* \dagger}$ Rainer F. Winter, ${ }^{\ddagger}$ and Elisabeth Kaifer ${ }^{\dagger}$ \\ Anorganisch-Chemisches Institut der Universität Heidelberg, Im Neuenheimer Feld 270, \\ D-69120 Heidelberg, Germany, and Institut für Anorganische Chemie der Universität Stuttgart, \\ Pfaffenwaldring 55, D-70569 Stuttgart, Germany
}

Received March 6, 2001

\begin{abstract}
An extremely bent cyanide coordination at a dinickel scaffold is reported. Preorganization of two nickel ions is achieved by means of a compartmental dinucleating pyrazolate ligand $\mathrm{L}^{-}$, setting up a bimetallic coordination pocket with constrained metal-metal separation. The mixed-spin dinickel(II) complex $\left[\mathrm{LNi}_{2}(\mathrm{CN})(\mathrm{MeCN})\right](\mathrm{ClO})_{2}$ (1) has been characterized by X-ray diffraction. The MeCN bound to the high-spin nickel(II) ion can be removed or replaced by other ligands, e.g., by the cyanide ligand of a tetracyanonickelate(II) moiety to give the starlike nonanuclear complex $\left\{\left[\mathrm{LNi}_{2}(\mathrm{CN})\right]_{4}\left[\mathrm{Ni}(\mathrm{CN})_{4}\right]\right\}\left(\mathrm{ClO}_{4}\right)_{6}(2)$ that contains four of the constrained pyrazolate-based dinickel(II) fragments grouped around a central tetracyanonickelate(II) unit, as revealed by X-ray crystallography. Spectral and electrochemical properties of $\mathbf{1}$ and $\mathbf{2}$ are reported, and the formation of reduced mixed-valent $\mathrm{Ni}^{\mathrm{I}} \mathrm{Ni}^{\mathrm{II}}$ species is investigated by IR and UV/vis spectroelectrochemistry.
\end{abstract}

\section{Introduction}

Current interest in oligonuclear transition metal complexes is often inspired by the prospect of distinct reactivity patterns or interesting physicochemical properties that may arise from the cooperative action of the adjacent metal centers. ${ }^{1,2}$ With regard to bimetallic reactivity much effort has been devoted to the design of elaborate dinucleating ligand matrixes that provide two coordination compartments in order to hold two metal ions in suitable proximity. ${ }^{3}$ Multidentate pyrazole derivatives have proven to be valuable ligand scaffolds for this purpose, as the metal-metal separation and individual coordination environments can be selectively altered by appropriate changes of chelating donor sidearms attached to the bridging heterocycle. ${ }^{4-7}$ The constrained preorganization of two metal ions in such pyrazolate-based dinuclear complexes has allowed the observation of unusual binding modes of small molecules within the bimetallic pocket, e.g., the enforced side-on $\pi$-interaction of a nitrile unit with a high-spin nickel(II) site. $^{8}$

* To whom correspondence should be addressed. Fax: (0049)-6221545707. E-mail: franc.meyer@urz.uni-heidelberg.de.

† Anorganisch-Chemisches Institut der Universität Heidelberg.

$\doteqdot$ Institut für Anorganische Chemie der Universität Stuttgart.

(1) (a) Steinhagen, H.; Helmchen, G. Angew. Chem., Int. Ed. Engl. 1996, 35, 2339. (b) McCollum, D. G.; Bosnich, B. Inorg. Chim. Acta 1998, 270, 13-19. (c) van den Beuken, E. K.; Feringa, B. L. Tetrahedron 1998, 54, 12985-13011.

(2) (a) Kahn, O. Angew. Chem., Int. Ed. Engl. 1985, 24, 834. (b) Kahn, O. Adv. Inorg. Chem. 1995, 43, 179-259.

(3) (a) Fenton, D. E.; Okawa, H. Chem. Ber./Recl. 1997, 130, 433-442. (b) Collinson, S. R.; Fenton, D. E. Coord. Chem. Rev. 1996, 148, 19-40.

(4) (a) Meyer, F.; Beyreuther, S.; Heinze, K.; Zsolnai, L. Chem. Ber./ Recl. 1997, 130, 605-613. (b) Buchler, S.; Meyer, F.; Jacobi, A.; Kircher, P.; Zsolnai, L. Z. Naturforsch. 1999, 54b, 1295-1306.

(5) Meyer, F.; Ruschewitz, U.; Schober, P.; Antelmann, B.; Zsolnai, L. J. Chem. Soc., Dalton Trans. 1998, 1181-1186.

(6) (a) Meyer, F.; Heinze, K.; Nuber, B.; Zsolnai, L. J. Chem. Soc., Dalton Trans. 1998, 207-213. (b) Meyer, F.; Rutsch, P. Chem. Commun. 1998, 1037-1038.

(7) Konrad, M.; Meyer, F.; Heinze, K.; Zsolnai, L. J. Chem. Soc., Dalton Trans. 1998, 199-205.
In pursuit of special physicochemical phenomena arising from the cooperativity of several metal ions, such as magnetic ordering or electronic interactions, simple and tight-binding bridging ligands are employed preferentially for the construction of extended and ordered metal arrays. The bidentate cyanide ligand has played a major role in this field, as it is able to facilitate long-range electron transfer and to mediate magnetic exchange interactions. ${ }^{9-12}$ In addition, it generally forms extraordinarily stable complexes that allow for the construction of two- and three-dimensional arrays of cyanide-based coordination units. ${ }^{12}$

In the present contribution we combine the use of a multidentate compartmental ligand platform and of cyanide chemistry to (i) enforce an extremely bent cyanide binding mode within a predefined bimetallic pocket and (ii) assemble an unusual starlike nickel complex of higher nuclearity from such bimetallic building blocks. Structural features of these novel systems are reported, in particular the most acute $\mathrm{C} \equiv \mathrm{N}-\mathrm{M}$ angles known

(8) Meyer, F.; Hyla-Kryspin, I.; Kaifer, E.; Kircher, P. Eur. J. Inorg. Chem. 2000, 771-781.

(9) (a) Shriver, D. F. Struct. Bonding 1966, 1, 32-58. (b) Dunbar, K. M.; Heintz, R. A. Prog. Inorg. Chem. 1997, 45, 283-391. (c) Scandola, F.; Argazzi, R.; Bignozzi, C. A.; Chiorboli, C.; Indelli, M T.; Rampi, M. A. Coord. Chem. Rev. 1993, 125, 283-292. (d) Vahrenkamp, H.; Geiss, A.; Richardson, G. N. J. Chem. Soc., Dalton Trans. 1997, 3643-3651. (e) Ohba, M.; Okawa, H. Coord. Chem. Rev. 2000, 198, 313-328.

(10) (a) Geiss, A.; Vahrenkamp, H. Eur. J. Inorg. Chem. 1999, 17931803. (b) Richardson, G. N.; Brand, U.; Vahrenkamp, H. Inorg. Chem. 1999, 38, 3070-3079.

(11) (a) Klausmeyer, K. K.; Rauchfuss, S. R. Angew. Chem., Int. Ed. 1998 37, 1694-1696. (b) Marvilliers, A.; Parsons, S.; Rivière, E.; Audière, J.-P.; Mallah, T. Chem. Commun. 1999, 2217-2218. (c) Oshio, H.; Onodera, H.; Tamada, O.; Mizutani, H.; Hikichi, T.; It, T. Chem.Eur. J. 2000, 6, 2523-2530. (d) Parker, R. J.; Spiccia, L.; Berry, K. J.; Fallon, G. D.; Moubaraki, B.; Murray, K. S. Chem. Commun. 2001, 333-334.

(12) (a) Ferlay, S.; Mallah, T.; Ouahès, R.; Veillet, P.; Verdaguer, M. Nature 1995, 378, 701-703. (b) Sato, O.; Iyoda, T.; Fujishima, A.; Hashimoto, K. Science 1996, 271, 49-51. (c) Pilkington, M.; Decurtins, S. Chimia 2000, 54, 593-601 
to date for $\mu_{2}-\kappa \mathrm{C}: \kappa \mathrm{N}$-cyanide $\left(111.2-112.9^{\circ}\right)$, and redox phenomena mediated by the cyanide bridges are studied.

\section{Experimental Section}

General Procedures and Methods. All manipulations were carried out under an atmosphere of dry nitrogen by employing standard Schlenk techniques. Solvents were dried according to established procedures. HL was synthesized according to the reported method; ${ }^{4 a}$ all other chemicals were used as purchased. Microanalyses: Mikroanalytische Laboratorien des Organisch-Chemischen Instituts der Universität Heidelberg. IR spectra: Perkin-Elmer 983G; recorded as $\mathrm{KBr}$ pellets. MS spectra: Finnigan MAT 8230 (FAB) or Finnigan TSQ 700 (ESI). UV/vis spectra: Perkin-Elmer Lambda 19. Magnetic measurement: Bruker Magnet B-E 15 C8, field controller B-H 15, variable temperature unit ER4111VT, Sartorius micro balance M 25 D-S. Experimental susceptibility data were corrected for the underlying diamagnetism. Cyclic voltammetry: PAR equipment (potentiostat/galvanostat 273), in $0.1 \mathrm{M} \mathrm{NBu}_{4} \mathrm{PF}_{6} \mathrm{MeCN}$ solution. Potentials in volts on glassy carbon electrode, referenced to the SCE at ambient temperature. Spectroelectrochemistry: Self-constructed OTTLE cell comprising a Pt-mesh working and counter electrode and a silver wire as pseudo reference electrode sandwiched in between the $\mathrm{CaF}_{2}$ windows of a conventional liquid IR cell. The working electrode is positioned in the center of the spectrometer beam with all other parts of the cell made nontransparent to the incident beam by means of an absorbing tape. ${ }^{25}$

CAUTION! Although no problems were encountered in this work, transition metal perchlorate complexes are potentially explosive and should be handled with proper precautions.

Synthesis of 1. A solution of HL $(250 \mathrm{mg}, 0.48 \mathrm{mmol})$ in ethanol $(30 \mathrm{~mL})$ was treated with 1 equiv of $\mathrm{KO}^{t} \mathrm{Bu}(54 \mathrm{mg})$ and 2 equiv of $\left[\mathrm{Ni}\left(\mathrm{H}_{2} \mathrm{O}\right)_{6}\right]\left(\mathrm{ClO}_{4}\right)_{2}(350 \mathrm{mg}, 0.96 \mathrm{mmol})$. After stirring for $30 \mathrm{~min}$, $\left[\mathrm{NEt}_{4}\right] \mathrm{CN}$ (73 mg, $0.47 \mathrm{mmol}$ ) was added in one portion. The reaction mixture was stirred for a further $1 \mathrm{~h}$ and was filtered. Evaporation of all volatile material under reduced pressure afforded a green residue, which was redissolved in acetonitrile. Layering the solution with diethyl ether gradually gave green crystals of $\mathbf{1} \cdot 1.4 \mathrm{MeCN}$ (300 mg, 69\%). IR $\left(\mathrm{KBr}, \mathrm{cm}^{-1}\right): 2964(\mathrm{~m}), 2877(\mathrm{w}), 2284\left[\mathrm{w}, v(\mathrm{C} \equiv \mathrm{N})_{\mathrm{MeCN}}\right], 2245[\mathrm{w}$, $\left.v(\mathrm{C} \equiv \mathrm{N})_{\mathrm{MeCN}}\right], 2106\left[\mathrm{~m}, v(\mathrm{C} \equiv \mathrm{N})_{\mathrm{CN}}\right], 1461(\mathrm{~s}), 1383(\mathrm{~m}), 1305(\mathrm{w})$, $1088\left[\mathrm{vs}, v\left(\mathrm{ClO}_{4}\right)\right], 795(\mathrm{~m}), 739(\mathrm{~m}), 623(\mathrm{~s})$. Drying the product under dynamic vacuum causes the IR spectrum to change as follows and yields 1': IR (KBr, cm $\left.{ }^{-1}\right)$ : $2971(\mathrm{~m}), 2874(\mathrm{w}), 2096\left[\mathrm{~m}, v(\mathrm{C} \equiv \mathrm{N})_{\mathrm{CN}}\right], 1468$ (s), $1384(\mathrm{~m}), 1300(\mathrm{w}), 1090$ [vs, $v\left(\mathrm{ClO}_{4}\right)$ ], $792(\mathrm{~m}), 737(\mathrm{~m}), 623$ (s). MS $(\mathrm{FAB}+)\left[\mathrm{m} / \mathrm{z}\right.$ (relative intensity)]: $762(100)\left[\mathrm{LNi}_{2}(\mathrm{CN})\right.$ $\left.\left(\mathrm{ClO}_{4}\right)\right]^{+}, 663(75)\left[\mathrm{LNi}_{2}(\mathrm{CN})\right]^{+}$. Anal. Calcd for $\mathrm{C}_{30} \mathrm{H}_{61} \mathrm{Cl}_{2} \mathrm{~N}_{9} \mathrm{Ni}_{2} \mathrm{O}_{8}$ $\left[\mathrm{LNi}_{2}(\mathrm{CN})\left(\mathrm{ClO}_{4}\right)_{2}, \mathbf{1}^{\prime}\right]: \mathrm{C}, 41.69 ; \mathrm{H}, 7.11 ; \mathrm{N}, 14.59$. Found: C, 41.16; H, 7.22; N, 13.62.

Synthesis of 2. The synthesis is similar to the procedure described for 1 starting from HL (250 mg, $0.48 \mathrm{mmol})$, but almost 2 equiv of [NEt 4 ]CN (145 mg, $0.93 \mathrm{mmol}$ ) was added. Purification was achieved by diffusion of diethyl ether into a solution of the product in acetone/ wet methanol $(1: 1)$, which yielded $2 \cdot 0.5 \mathrm{H}_{2} \mathrm{O}$ as greenish-yellow crystals (280 mg, 68\% with respect to HL). IR ( $\left.\mathrm{KBr}, \mathrm{cm}^{-1}\right): 2962(\mathrm{~m}), 2869$ $(\mathrm{w}), 2159[\mathrm{~m}, v(\mathrm{C} \equiv \mathrm{N})], 2107[\mathrm{~m}, v(\mathrm{C} \equiv \mathrm{N})], 1518(\mathrm{w}), 1453(\mathrm{~m}), 1376$ (m), 1341 (w), 1309 (w), 1094 [vs, v( $\left.\mathrm{ClO}_{4}\right)$ ], 794 (m), 739 (m), 622 (s). MS $(\mathrm{FAB}+)\left[\mathrm{m} / \mathrm{z}\right.$ (relative intensity)]: $1592(35)\left\{\left[\mathrm{LNi}_{2}(\mathrm{CN})\right]_{2^{-}}\right.$ $\left.\mathrm{Ni}(\mathrm{CN})_{4}\left(\mathrm{ClO}_{4}\right)\right\}^{+}, 764(60)\left[\mathrm{LNi}_{2}(\mathrm{CN})\left(\mathrm{ClO}_{4}\right)\right]^{+}, 689(65)\left[\mathrm{LNi}_{2}(\mathrm{CN})_{2}\right]^{+}$, $663(100)\left[\mathrm{LNi}_{2}(\mathrm{CN})\right]^{+}$. MS (ESI+) $[\mathrm{m} / z$ (relative intensity)]: 1592 (5) $\left\{\left[\mathrm{LNi}_{2}(\mathrm{CN})\right]_{2} \mathrm{Ni}(\mathrm{CN})_{4}\left(\mathrm{ClO}_{4}\right)\right\}^{+}, 1519(10)\left\{\left[\mathrm{LNi}_{2}(\mathrm{CN})\right]_{2} \mathrm{Ni}(\mathrm{CN})_{4^{-}}\right.$ $\left.\left(\mathrm{ClO}_{4}\right)-\mathrm{HNEt}_{2}\right\}^{+}, 764(20)\left[\mathrm{LNi}_{2}(\mathrm{CN})\left(\mathrm{ClO}_{4}\right)\right]^{+}, 746(90)\left\{\left[\mathrm{LNi}_{2}(\mathrm{CN})\right]_{2^{-}}\right.$ $\left.\mathrm{Ni}(\mathrm{CN})_{4}\right\}^{2+}, 689(100)\left[\mathrm{LNi}_{2}(\mathrm{CN})_{2}\right]^{+}$. MS (ESI-) $[\mathrm{m} / z$ (relative intensity)]: 1790 (10) $\left\{\left[\mathrm{LNi}_{2}(\mathrm{CN})\right]_{2} \mathrm{Ni}(\mathrm{CN})_{4}\left(\mathrm{ClO}_{4}\right)_{3}\right\}^{-}, 962$ (5) $\left[\mathrm{LNi}_{2}(\mathrm{CN})\left(\mathrm{ClO}_{4}\right)_{3}\right]^{-}$. Anal. Calcd for $\mathrm{C}_{124} \mathrm{H}_{244} \mathrm{Cl}_{6} \mathrm{~N}_{40} \mathrm{Ni}_{9} \mathrm{O}_{24} \cdot 0.5 \mathrm{H}_{2} \mathrm{O}$ : C, 43.43; H, 7.20; N, 16.34. Found: C, 43.15; H, 7.23; N, 15.95.

X-ray Crystallography. The measurements were carried out on a Nonius Kappa CCD diffractometer using graphite-monochromated Mo $\mathrm{K} \alpha$ radiation. All calculations were performed using the SHELXT PLUS software package. Structures were solved by direct methods with the SHELXS-97 and refined with the SHELXL-97 program. ${ }^{13}$ Atomic coordinates and thermal parameters of the non-hydrogen atoms were refined in fully or partially anisotropic models by full-matrix least-
Table 1. Crystal Data and Refinement Details for Complexes 1 and 2

\begin{tabular}{|c|c|c|}
\hline & $\mathbf{1} \cdot 1.4 \mathrm{MeCN}$ & $\mathbf{2} \cdot 0.5 \mathrm{H}_{2} \mathrm{O}$ \\
\hline formula & $\begin{array}{c}\mathrm{C}_{32} \mathrm{H}_{64} \mathrm{C}_{12} \mathrm{~N}_{10} \mathrm{Ni}_{2} \mathrm{O}_{8} \\
1.4 \mathrm{MeCN}\end{array}$ & $\begin{array}{l}\mathrm{C}_{124} \mathrm{H}_{244} \mathrm{C}_{16} \mathrm{~N}_{40} \mathrm{Ni}_{9} \mathrm{O}_{24}{ }^{\circ} \\
0.5 \mathrm{H}_{2} \mathrm{O}\end{array}$ \\
\hline$M_{\mathrm{r}}$ & 962.68 & 3420.49 \\
\hline cryst size (mm) & $0.40 \times 0.25 \times 0.15$ & $0.20 \times 0.15 \times 0.05$ \\
\hline cryst syst & orthorhombic & triclinic \\
\hline space group & $P 2_{1} 2_{1} 2_{1}$ & $P \overline{1}$ \\
\hline$a(\AA)$ & $13.717(3)$ & $20.593(4)$ \\
\hline$b(\AA)$ & $14.054(3)$ & 20.793(4) \\
\hline$c(\AA)$ & $24.374(5)$ & $21.034(4)$ \\
\hline$\alpha(\operatorname{deg})$ & 90 & $90.79(3)$ \\
\hline$\beta(\operatorname{deg})$ & 90 & $95.78(3)$ \\
\hline$\gamma(\operatorname{deg})$ & 90 & $110.32(3)$ \\
\hline$V\left(\AA^{3}\right)$ & 4699(1) & $8392(1)$ \\
\hline$\rho_{\text {calcd }}\left(\mathrm{g} \mathrm{cm}^{-3}\right)$ & 1.361 & 1.344 \\
\hline$Z$ & 4 & 2 \\
\hline$F(000)(\mathrm{e})$ & 2043 & 3604 \\
\hline$T(\mathrm{~K})$ & 200 & 200 \\
\hline$\mu(\operatorname{Mo~K} \alpha)\left(\mathrm{mm}^{-1}\right)$ & 0.972 & 1.151 \\
\hline scan mode & $\omega$ & $\omega$ \\
\hline$h k l$ range & $\begin{array}{l}-12 \text { to } 17,-14 \text { to } 18, \\
-24 \text { to } 31\end{array}$ & $\begin{array}{l}-28 \text { to } 28,-28 \text { to } 28 \\
-29 \text { to } 29\end{array}$ \\
\hline $2 \theta$ range (deg) & $3.3-55.0$ & $2.7-59.6$ \\
\hline measd reflns & 23592 & 90732 \\
\hline unique reflns & 10783 & 46588 \\
\hline obsd reflns $[I>2 \sigma(I)]$ & 9031 & 20687 \\
\hline refined params & 602 & 1854 \\
\hline $\begin{array}{l}\text { resid electron dens } \\
\quad\left(\mathrm{e} \AA^{-3}\right)\end{array}$ & $0.68 /-0.41$ & $1.66 /-1.14$ \\
\hline $\mathrm{R} 1$ & 0.044 & 0.083 \\
\hline $\begin{array}{l}\text { wR2 (refinement } \\
\text { on } F^{2} \text { ) }\end{array}$ & 0.122 & 0.269 \\
\hline goodness-of-fit & 1.005 & 1.000 \\
\hline
\end{tabular}

\section{Chart 1}

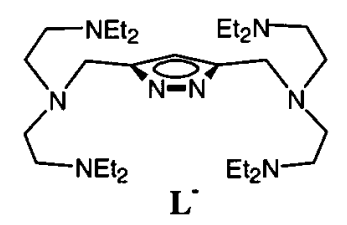

squares calculations based on $F^{2}$. In general the hydrogen atoms were placed at calculated positions and allowed to ride on the atoms to which they are attached. For $\mathbf{1}, \mathrm{MeCN}$ solvent molecules are included at two positions in the unit cell, each one having an occupancy of $70 \%$. The only moderate quality of the structural analysis of $\mathbf{2}$ mainly results from severe disorder of some of the perchlorate counteranions. Also, most of the residual electron density is located in the vicinity of the perchlorate. Part of the perchlorate $\mathrm{O}$ atoms could not be refined anisotropically. Data for $\mathbf{2}$ have been collected to rather high $2 \theta$ values in order to obtain a reasonable reflex/parameter ratio. Table 1 compiles the data for the structure determinations.

\section{Results and Discussion}

Synthesis and Structural Characterization. The dinucleating pyrazole ligand HL is employed in the present work. ${ }^{4 a}$ Its anionic form, $\mathrm{L}^{-}$(Chart 1), has previously been shown to bind two metal ions in its adjacent coordination compartments, setting up a central bimetallic pocket in which additional ligands or substrate molecules may be held within the grip of the two metals. ${ }^{6,8,14}$ As enforced by the particular length of the ligand

(13) Sheldrick, G. M. SHELXL-97, Program for Crystal Structure Refinement; Universität Göttingen: Göttingen, 1997. Sheldrick, G. M SHELXS-97, Program for Crystal Structure Solution; Universität Göttingen: Göttingen, 1997.

(14) (a) Meyer, F.; Pritzkow, H. Chem. Commun. 1998, 1555-1556. (b) Meyer, F.; Kaifer, E.; Kircher, P.; Heinze, K.; Pritzkow, H. Chem.Eur. J. 1999, 5, 1617-1630. 


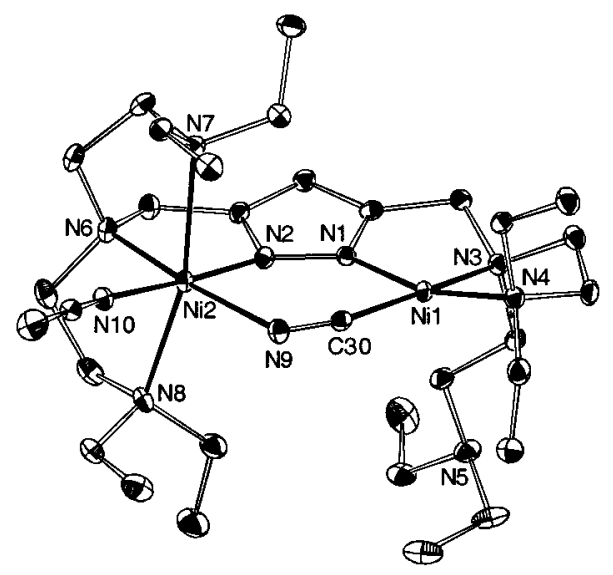

Figure 1. View of the molecular structure of the cation of 1 (40\% probability ellipsoids). In the interest of clarity all hydrogen atoms have been omitted.

\section{Chart 2}

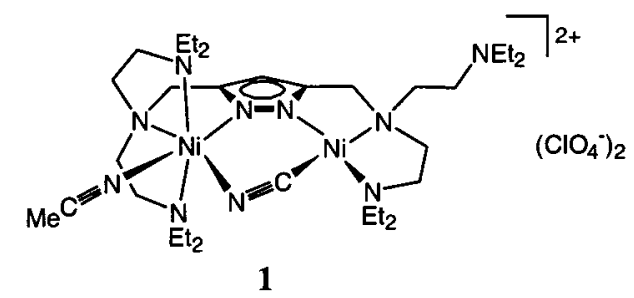

sidearms, the metal-metal separation in complexes of $\mathrm{L}^{-}$is too large for allowing small ligands like $\mathrm{OH}^{-}$to form a monatomic secondary bridge within the bimetallic pocket. ${ }^{6}$ On the other hand, molecular models suggest that incorporation of two-atom bridges that prefer linear coordination, e.g., the cyanide ion in $\mathrm{M}-\mathrm{CN}-\mathrm{M}$ fragments, is strongly disfavored due to the geometrical constraints imposed by the dinuclear scaffold.

Addition of 1 equiv of $\left[\mathrm{NEt}_{4}\right] \mathrm{CN}$ to an in situ prepared dinickel(II) complex of $\mathrm{L}^{-}$in acetonitrile afforded a green solution, from which greenish-yellow crystals of the new complex 1 could be isolated (Chart 2). Binding of cyanide was indicated by FAB mass spectrometry, showing major signals for $\left[\mathrm{LNi}_{2}(\mathrm{CN})\left(\mathrm{ClO}_{4}\right)\right]^{+}$and $\left[\mathrm{LNi}_{2}(\mathrm{CN})\right]^{+}$with the expected isotopic distribution patterns. The molecular structure of $\mathbf{1}$ was revealed by X-ray crystallography, the result of which is depicted in Figure 1. Selected interatomic distances and bond angles are listed in Table 2.

As anticipated, the two nickel ions in $\mathbf{1}$ are nested within their respective coordination compartments and are spanned by the pyrazolate moiety. The cyanide ligand is housed within the bimetallic pocket, thereby inducing a pronounced asymmetry of the dinuclear framework. Assignment of the $\mathrm{C}$ and $\mathrm{N}$ atoms of the cyanide was based on the clearly different quality of the two crystallographic models for both alternative orientations, and on the geometric characteristics discussed in the following: as expected for the strong-field cyanide ligand, the Ni1 ion bound to the cyanide $\mathrm{C}$ is found in a square planar environment, which leaves one of the respective ligand sidearms uncoordinated and dangling. In contrast, $\mathrm{Ni} 2$ bound to the cyanide $\mathrm{N}$ is six-coordinate due to the attachment of an additional MeCN solvent molecule in an exo position cis to the cyanide and trans to the pyrazolate nitrogen atom. Magnetic susceptibility measurements on a powdered sample of $\mathbf{1}$ confirm the presence of a mixed-spin complex with only one high-spin nickel(II) ion $(S=1)$ per bimetallic entity.

While the N9-C30 bond length [1.152(4) $\AA]$ is in the normal range, other geometric parameters around the bridging cyanide

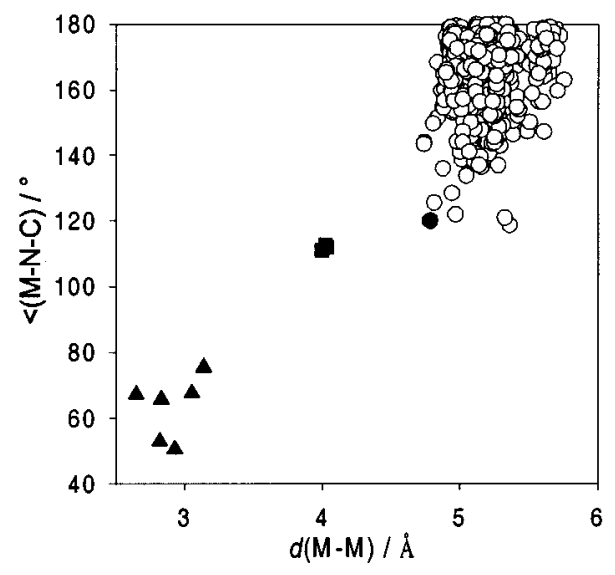

Figure 2. Scatter plot showing the correlation between the metalmetal distance $d(\mathbf{M}-\mathbf{M})$ and the angle $\mathrm{M}-\mathrm{N}-\mathrm{C}$ for cyanide-bridged complexes obtained from a CSD search: ${ }^{16}(O)$ complexes with $\mu_{2}-\kappa \mathrm{C}$ : $\kappa \mathrm{N}$-cyanide; $(\bullet) \mathrm{PtCu}$ complex reported by Falvello et al.; ${ }^{15}$ (ם) complexes $\mathbf{1}$ and $\mathbf{2}$; $(\mathbf{\Lambda})$ complexes with $\mu_{2}-\kappa \mathrm{C}: \eta^{2}-\mathrm{C}, \mathrm{N}$-cyanide. ${ }^{17}$

Table 2. Selected Interatomic Distances $(\AA)$ and Bond Angles (deg) for 1

\begin{tabular}{lrll}
\hline Ni1-N1 & $1.845(3)$ & Ni2-N7 & $2.335(3)$ \\
Ni1-N3 & $1.945(3)$ & Ni2-N8 & $2.254(3)$ \\
Ni1-N4 & $1.933(3)$ & Ni2-N9 & $2.198(3)$ \\
Ni1-C30 & $1.863(4)$ & Ni2-N10 & $2.056(3)$ \\
Ni2-N2 & $2.029(3)$ & Ni1 $\cdots$ Ni2 & 4.002 \\
Ni2-N6 & $2.094(3)$ & & \\
N1-Ni1-N3 & $83.9(1)$ & N9-Ni2-N2 & $91.8(1)$ \\
N3-Ni1-N4 & $89.4(1)$ & N9-Ni2-N7 & $97.4(1)$ \\
N4-Ni1-C30 & $99.3(1)$ & N9-Ni2-N8 & $97.3(1)$ \\
C30-Ni1-N1 & $88.3(1)$ & N9-Ni2-N10 & $88.7(1)$ \\
N1-Ni1-N4 & $164.2(1)$ & N2-Ni2-N6 & $80.3(1)$ \\
C30-Ni1-N3 & $170.9(1)$ & N2-Ni2-N7 & $89.4(1)$ \\
Ni1-C30-N9 & $162.1(3)$ & N2-Ni2-N8 & $94.2(1)$ \\
C30-N9-Ni2 & $111.2(2)$ & N6-Ni2-N7 & $82.1(1)$ \\
N9-Ni2-N6 & $172.1(1)$ & N6-Ni2-N8 & $84.0(1)$ \\
N2-Ni2-N10 & $177.0(1)$ & N6-Ni2-N10 & $99.2(1)$ \\
N7-Ni2-N8 & $164.8(1)$ & N10-Ni2-N7 & $87.6(1)$ \\
& & N10-Ni2-N8 & $88.7(1)$
\end{tabular}

ligand are quite unusual. The bond angle Ni1-C30-N9 is relatively small $\left[162.1(3)^{\circ}\right]$, and the angle Ni2-N9-C30 is extremely acute for a $\mu_{2}-\kappa \mathrm{C}: \kappa \mathrm{N}$-cyanide $\left[111.2(2)^{\circ}\right]$, which apparently is enforced by the fixed metal-metal separation and the rigidity of the bimetallic scaffold. A different case of a severely bent cyanide bridging between a platinum(II) and a copper(II) has recently been observed by Falvello et al. (angle $\left.\mathrm{C} \equiv \mathrm{N}-\mathrm{Cu}: 120.1(6)^{\circ}\right) .{ }^{15}$ In that compound, the two metal ions are not linked by any other ligand than the bent cyanide, and the deformation from linearity is traced to a collection of noncovalent intermolecular and intramolecular H-bonding interactions in the solid state.

The strong deviation of the situation encountered in $\mathbf{1}$ from the more conventional geometric patterns of cyanide binding is evidenced by a scatter plot showing the $\mathrm{M} \cdot \cdots \mathrm{M}$ distances versus the $\mathrm{M}-\mathrm{N}-\mathrm{C}$ angles for $454 \mathrm{M}-\mathrm{CN}-\mathrm{M}$ fragments obtained from a CSD search as depicted in Figure 2. ${ }^{16}$ Metalmetal distances for bridging $\mu_{2}-\kappa \mathrm{C}: \kappa \mathrm{N}$-cyanide are usually found in the range $4.75-5.75 \AA$, and angles $\mathrm{C} \equiv \mathrm{N}-\mathrm{M}$ at the cyanide $\mathrm{N}$ generally lie above $120^{\circ}(\mathrm{O}$; the $\mathrm{PtCu}$ complex reported by

(15) Escorihuela, I.; Falvello, L. R.; Tomás, M. Inorg. Chem. 2001, 40, 636-640.

(16) Cambridge Structural Database search conducted in November 2000 Allen, F. H.; Davis, J. E.; Galloy, J. J.; Johnson, O.; Kennard, O. Macrae, C. F.; Mitchell, E. M.; Mitchell, G. F.; Smith, J. M.; Watson, D. G. J. Chem. Inf. Comput. Sci. 1991, 31, 187. 
Table 3. Selected Interatomic Distances $(\AA)$ and Bond Angles (deg) for $\mathbf{2}^{a}$

\begin{tabular}{|c|c|}
\hline $\mathrm{Ni1}-\mathrm{C} 30$ & $1.853(6) / 1.860(6) / 1.862(6) / 1.854(6)$ \\
\hline C30-N9 & $1.158(7) / 1.163(7) / 1.156(7) / 1.158(7)$ \\
\hline Ni2-N9 & $2.209(5) / 2.197(5) / 2.199(5) / 2.239(5)$ \\
\hline $\mathrm{Ni2}-\mathrm{N} 10$ & $2.038(5) / 2.029(5) / 2.042(5) / 2.033(5)$ \\
\hline $\mathrm{N} 10-\mathrm{C} 31$ & $1.144(7) / 1.157(7) / 1.146(7) / 1.158(7)$ \\
\hline $\mathrm{Ni9}-\mathrm{C} 31$ & $1.881(6) / 1.867(6) / 1.875(6) / 1.863(6)$ \\
\hline $\mathrm{Ni} 1 \cdots \mathrm{Ni} 2$ & $4.022 / 3.997 / 4.024 / 4.033$ \\
\hline $\mathrm{Ni} 2 \cdots \mathrm{Ni} 9$ & $5.031 / 4.980 / 5.024 / 5.027$ \\
\hline $\mathrm{Ni} 1-\mathrm{C} 30-\mathrm{N} 9$ & $161.6(5) / 160.7(5) / 160.5(5) / 160.7(5)$ \\
\hline $\mathrm{C} 30-\mathrm{N} 9-\mathrm{Ni} 2$ & $112.0(4) / 111.2(4) / 112.9(4) / 112.0(4)$ \\
\hline $\mathrm{Ni2}-\mathrm{N} 10-\mathrm{C} 31$ & $168.6(5) / 166.0(5) / 168.9(5) / 168.8(4)$ \\
\hline $\mathrm{N} 10-\mathrm{C} 31-\mathrm{Ni} 9$ & $176.9(5) / 171.5(6) / 174.7(6) / 177.3(5)$ \\
\hline
\end{tabular}

${ }^{a}$ Atom numbering refers to the Ni1/Ni2 subunit, but the corresponding values for the $\mathrm{Ni3} / \mathrm{Ni} 4, \mathrm{Ni} 5 / \mathrm{Ni}$, and $\mathrm{Ni7} / \mathrm{Ni} 8$ subunits are also listed.

Table 4. IR Absorptions in the $\mathrm{C} \equiv \mathrm{N}$ Stretching Range (Values in $\left.\mathrm{cm}^{-1}\right)$

\begin{tabular}{ll}
\hline $\mathbf{1}^{a}$ & $2284,2245,2106$ \\
$\mathbf{1}^{\prime a}$ & 2096 \\
$\mathbf{1}^{b}$ & 2112 \\
$\mathbf{1}_{\text {red }^{b}}$ & $1950(\mathrm{sh}), 1905$ \\
$\mathbf{2}^{a}$ & 2159,2107 \\
$\mathbf{2}^{b}$ & 2160,2112 \\
$\mathbf{2}_{\text {red }^{\prime}}{ }^{b}$ & $2098,1950(\mathrm{sh}), 1905$
\end{tabular}

${ }^{a} \mathrm{KBr}$ pellet. ${ }^{b} \mathrm{In} \mathrm{MeCN}$ solution.

Falvello et al. ${ }^{15}$ is highlighted as a solid circle). In contrast, the $\mathrm{Ni} \cdots \mathrm{Ni}$ distance in $\mathbf{1}$ is fixed at only $4.002 \AA$, thus causing the extreme bending of the $\mathrm{Ni}-\mathrm{C} \equiv \mathrm{N}-\mathrm{Ni}$ fragment (ם). Also included in Figure 2 are those values for the related complex 2 described below and for the few crystallographically characterized systems where $\mu_{2}-\kappa \mathrm{C}: \eta^{2}-\mathrm{C}, \mathrm{N}$ bridging of a cyanide ligand has been observed $(\boldsymbol{\Delta}) .{ }^{17}$ In these latter cases the metal ions that exhibit $\eta^{2}$ side-on $\pi$-bonding to the $\mathrm{C} \equiv \mathrm{N}$ cyanide bond are electron-rich, low-valent $4 \mathrm{~d} / 5 \mathrm{~d}$-transition metals well capable of $\pi$-back-bonding, and the bimetallic scaffolds feature short $\mathrm{M}-\mathrm{M}$ distances due to metal-metal bonds, which is clearly different from the situation in $\mathbf{1}$. Enforced by the geometric constraints of the pyrazolate ligand, $\mathbf{1}$ adopts geometric parameters en route to such rare $\eta^{2} \pi$-bonding of the bridging cyanide, although any side-on $\pi$-interaction is supposedly negligible because of the high-spin character and the relative "hardness" of the N-bound $\mathrm{Ni} 2$ ion. It should be noticed, however, that some weak side-on $\pi$-interaction with a high-spin nickel(II) ion could be enforced for a nitrile $\mathrm{C} \equiv \mathrm{N}$ bonded within the highly preorganized bimetallic pocket of a similar dinickel(II) system. ${ }^{8}$

The IR spectrum $(\mathrm{KBr})$ of freshly prepared 1 shows a band for the $v(\mathrm{C} \equiv \mathrm{N})$ cyanide stretch at $2106 \mathrm{~cm}^{-1}$ (Table 4). Its somewhat higher frequency compared to the band position for free cyanide is not unexpected and is usually attributed to the kinematic coupling effect that occurs upon attachment of two metal ions to both ends of a cyanide. ${ }^{18}$ The observed band position for the $\mathrm{CN}$ stretch is by no means unusual for a $\mu_{2^{-}}$ $\kappa \mathrm{C}: \kappa \mathrm{N}$-cyanide, despite the unusual binding situation imposed

(17) (a) Curtis, M. D.; Han, K. R.; Butler, W. M. Inorg. Chem. 1980, 19, 2096-2101. (b) Deraniyaglia, S. P.; Grundy, K. R. Inorg. Chim. Acta 1984, 84, 205-211. (c) Balch, A. L.; Noll, B. C.; Olmstead, M. M.; Toronto, D. V. Inorg. Chem. 1993, 32, 3613-3619. (d) Bartley, S. L.; Bernstein, S. N.; Dunbar, K. R. Inorg. Chim. Acta 1993, 213, $213-$ 231. (e) Bear, J. L.; Li, Y.; Cui, J.; Han, B.; van Caemelbecke, E. Phan, T.; Kadish, K. M. Inorg. Chem. 2000, 39, 857-861. (f) Szalay, P. S.; Dunbar, K. R. Inorg. Chem. Commun. 2000, 3, 49-51.

(18) (a) Dows, D. A.; Haim, A.; Wilmarth, W. K. J. Inorg. Nucl. Chem. 1961, 21, 33. (b) Shriver, D. F. J. Am. Chem. Soc. 1963, 85, 14031405 . by the bimetallic scaffold. This is in accordance with the highspin +2 oxidation state of the nearby six-coordinate nickel(II) ion, as already discussed above: even if the positioning of $\mathrm{Ni} 2$ appears suitable for interaction with an antibonding $\pi^{*}$ orbital of the $\mathrm{CN}^{-}$ligand [which should lower $v(\mathrm{C} \equiv \mathrm{N})$ ], the relative "hardness" of the metal ion and the contracted character of its $3 \mathrm{~d}$ shell prevent any significant $\pi$-back-bonding.

An additional pair of bands appearing at 2245 and $2284 \mathrm{~cm}^{-1}$ in the IR spectrum of 1 results from the $v(\mathrm{C} \equiv \mathrm{N})$ stretching vibration of the terminally bound acetonitrile. When powdered material of the isolated complex $\mathbf{1}$ was dried under vacuum, a slight color change from greenish-yellow to green was observed. The IR spectrum of the new green material $\mathbf{1}$ ' displays no bands of coordinated acetonitrile and only one cyanide stretch at 2096 $\mathrm{cm}^{-1}$. Apparently, the acetonitrile ligand is only loosely bound, leading to its facile removal under reduced pressure and concomitant generation of an accessible coordination site at $\mathrm{Ni} 2$ (in the green compound $\mathbf{1}^{\prime}, \mathrm{Ni} 2$ presumably is five-coordinate similar to the situation in most other dinickel(II) complexes of the ligand $\left.\mathrm{L}^{-}\right) .{ }^{14}$ This vacant coordination site in $\mathbf{1}^{\prime}$ is now available for the binding of further cyanide building blocks, as demonstrated by the isolation of the starlike nonanuclear complex 2.

Complex 2 was originally obtained when a slight excess of $\left[\mathrm{NEt}_{4}\right] \mathrm{CN}$ was employed in the synthesis of $\mathbf{1}$, which obviously causes formation of the exceedingly stable $\left[\mathrm{Ni}(\mathrm{CN})_{4}\right]^{2-}$ ion $(K$ $\left.\approx 10^{31}\right) \cdot{ }^{19}$ Accordingly, 2 may also be prepared by treating 1 with the appropriate amount of a $\left[\mathrm{Ni}(\mathrm{CN})_{4}\right]^{2-}$ salt. An oligonuclear structure of $\mathbf{2}$ was inferred from the FAB-MS and ESIMS spectra, which revealed dominant peaks at $\mathrm{m} / \mathrm{z}=1592$ corresponding to $\left[\mathrm{LNi}_{2}(\mathrm{CN})\right]_{2} \mathrm{Ni}(\mathrm{CN})_{4}\left(\mathrm{ClO}_{4}\right)^{+}$(both FAB-MS and ESI-MS) and at $\mathrm{m} / \mathrm{z}=746$ corresponding to the dication $\left[\mathrm{LNi}_{2}(\mathrm{CN})\right]_{2} \mathrm{Ni}(\mathrm{CN})_{4}{ }^{2+}$ (only ESI-MS) with the expected isotopic distribution patterns. These findings already suggested the attachment of several $\left[\mathrm{LNi}_{2}(\mathrm{CN})\right]^{2+}$ bimetallic fragments to one $\left[\mathrm{Ni}(\mathrm{CN})_{4}\right]^{2-}$ group in 2 . Greenish-yellow single crystals suitable for X-ray crystallography could be obtained from acetone/wet methanol/diethyl ether. The molecular structure of the cation is shown in Figure 3, and selected interatomic distances and bond angles are listed in Table 3.

Complex 2 consists of four $\left[\mathrm{LNi}_{2}(\mathrm{CN})\right]^{2+}$ entities, each one similar to $\mathbf{1}$, that are held together by a central $\left[\mathrm{Ni}(\mathrm{CN})_{4}\right]^{2-}$ unit. Instead of the acetonitrile ligand in $\mathbf{1}$, a cyanide ligand of the central $\left[\mathrm{Ni}(\mathrm{CN})_{4}\right]^{2-}$ unit is now bound to the six-coordinate nickel(II) ions of all pyrazolate-based dinuclear fragments via its nitrogen atom. Geometric parameters of the four central cyanide ligands are ordinary, with $d(\mathrm{C} \equiv \mathrm{N})$ in the range 1.144$1.158 \AA$ and angles $\mathrm{C}-\mathrm{N}-\mathrm{Ni}$ between $166.0^{\circ}$ and $168.9^{\circ}$. In contrast, coordination of the outer four cyanide ligands deviates as severely from linearity as was found in $\mathbf{1}$ (compare Figure 2) with $d(\mathrm{C} \equiv \mathrm{N})$ in the range $1.156-1.163 \AA$ and angles $\mathrm{C}-\mathrm{N}-$ $\mathrm{Ni}$ between $111.2^{\circ}$ and $112.9^{\circ}$. The two types of cyanide ligands give rise to two IR absorptions at 2107 and $2159 \mathrm{~cm}^{-1}$, where the former is assigned to the bent $\mathrm{CN}$ ligands by comparison with the findings for $\mathbf{1}$ (Table 4). The difference in stretching frequency for the two kinds of bridging $\mathrm{CN}$ ligands in $\mathbf{2}$ can be traced to their different environment: the bent cyanide ligands receive full back-bonding from their respective $\mathrm{C}$-coordinated nickel ions, while the four linear $\mathrm{CN}$ ligands have to share the back-bonding ability of the central Ni9.

The $\left[\mathrm{Ni}(\mathrm{CN})_{4}\right]^{2-}$ unit has previously been employed as a bridging unit in multinuclear metal-cyanide systems. ${ }^{20,21}$

(19) Freund, H.; Schneider, C. R. J. Am. Chem. Soc. 1959, 81, 47804783. 


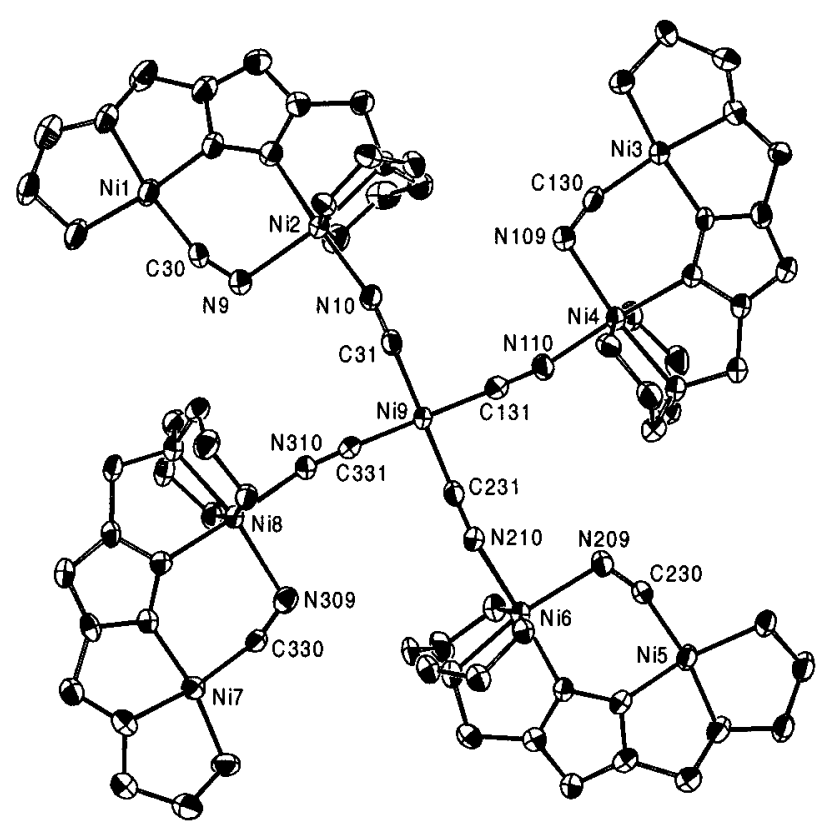

Figure 3. View of the molecular structure of the cation of $2(50 \%$ probability ellipsoids). In the interest of clarity all hydrogen atoms, all dangling ligand sidearms, and all N-bound ethyl groups have been omitted.

Table 5. UV/vis Absorptions of the Complexes [Values in $\mathrm{nm}(\epsilon$ in $\left.\left.\mathrm{M}^{-1} \mathrm{~cm}^{-1}\right)\right]$

\begin{tabular}{lc}
\hline $\mathbf{1}^{a}$ & $418(250), 621(20), 944(25), 1107(\mathrm{sh})$ \\
$\mathbf{1}^{\prime} b$ & $414(265), 650(50)$ \\
$\mathbf{1}_{\text {red }}{ }^{a}$ & $314(5100), 324(\mathrm{sh}), 356(5600), 380(\mathrm{sh}), 442(\mathrm{sh})$, \\
& $505(740), 1125(65), 1177(70)$ \\
$\mathbf{2}^{a}$ & $418(1125), 644(100), 955(110)$ \\
$\mathbf{2}_{\text {red }^{a}}{ }^{a}$ & $312(14000), 355(12800), 381(\mathrm{sh}), 440(\mathrm{sh}), 520(\mathrm{sh}, 1340)$, \\
& $805(410), 1105(385), 1185(375)$ \\
\multicolumn{1}{c}{${ }^{a}$ In $\mathrm{MeCN} .{ }^{b}$ In acetone/MeOH (2:1). }
\end{tabular}

However, very few detailed structures of discrete molecular complexes have been reported, in which the $\left[\mathrm{Ni}(\mathrm{CN})_{4}\right]^{2-}$ is linked to four metal ions via all of its terminal cyanide-N atoms ${ }^{21}$ and to the best of our knowledge the nonanuclear starlike topology of $\mathbf{2}$ involving three different types of nickel(II) ions is unprecedented.

Spectroscopy and Electrochemistry. Electronic absorptions of the different nickel(II) chromophores cannot be unambiguously assigned due to multiple transitions and partial overlap of the various bands. UV/vis data for $\mathbf{1}$ and $\mathbf{2}$ are collected in Table 5. Spectra of $\mathbf{1}$ are highly solvent dependent with pronounced differences when recorded in either $\mathrm{MeCN}$ or acetone/methanol (2:1) solution. This is attributed to dissociation of the MeCN ligand in the latter solvent mixture, leaving the respective metal ion five-coordinate in $\mathbf{1}^{\prime}$. Band positions for $\mathbf{2}$ in acetone/methanol $(2: 1)$ are almost identical to those of complex 1 in $\mathrm{MeCN}$ solution, in accordance with the above interpretation. While any bands below $350 \mathrm{~nm}$ (including the $\mathrm{d}-\mathrm{d}$ transition expected at $\sim 320 \mathrm{~nm}$ for the tetracyanonickelate(II) moiety in 2$)^{22}$ are obscured by intense $\pi \rightarrow \pi^{*}$ intraligand

(20) (a) Mann, K. R.; Duggan, D. M.; Hendrickson, D. N. Inorg. Chem. 1975, 14, 2577-2578. (b) Muga, I.; Gutiérrez-Zorilla, J. M.; Luque, A.; Román, P.; Lloret, F. Inorg. Chem. 1997, 36, 743-745. (c) Zhan, S.-Z.; Guo, D.; Zhang, X.-Y.; Du, C.-X.; Zhu, Y.; Yang, R.-N. Inorg. Chim. Acta 2000, 298, 57-62.

(21) (a) Berseth, P. A.; Sokol, J. J.; Shores, M. P.; Heinrich, J. L.; Long, J. R. J. Am. Chem. Soc. 2000, 122, 9655-9662. (b) Sokol, J. J.; Shores, M. P.; Long, J. R. Angew. Chem., Int. Ed. 2001, 40, 236-239.

(22) Gray, H. B. Transition Met. Chem. (N.Y.) 1965, 1, 239-287.

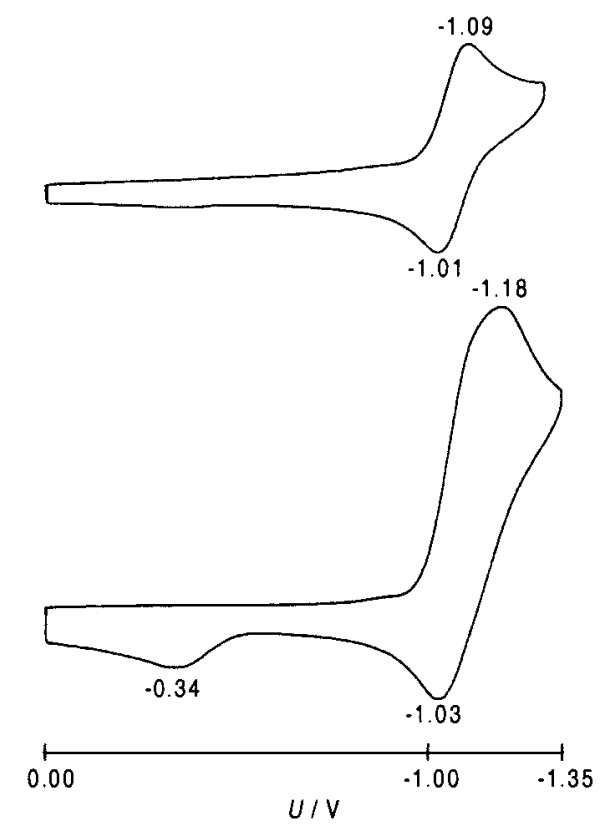

Figure 4. Cyclic voltammogram of complex $\mathbf{1} \cdot\left(\mathrm{ClO}_{4}\right)_{2}$ (a, top) and 2. $\left(\mathrm{ClO}_{4}\right)_{6}$ (b, bottom) recorded on a platinum electrode in $\mathrm{MeCN}$ containing $0.1 \mathrm{M} \mathrm{N}^{\mathrm{n}} \mathrm{Bu}_{4} \mathrm{PF}_{6}$ as supporting electrolyte at scan speed 200 $\mathrm{mV} \mathrm{s}^{-1}$. Indicated peak potentials are given in volts versus SCE.

features, all spectra are characterized by a strong band at 418 $(\mathbf{1}, \mathbf{2})$ or $414\left(\mathbf{1}^{\prime}\right) \mathrm{nm}$. This is assigned to the spin-allowed $\mathrm{d}_{x y}$ $\rightarrow \mathrm{d}_{x^{2}-y^{2}}$ transition of the square planar $\mathrm{LNi}(\mathrm{CN})$ fragment, indicating significant destabilization of the antibonding $\mathrm{d}_{x^{2}-y^{2}}$ orbital $\left(\mathrm{d}_{x y}-\mathrm{d}_{x^{2}-y^{2}}\right.$ separation $\left.\approx 24.000 \mathrm{~cm}^{-1}\right){ }^{23}$ A mediumintensity band at $650 \mathrm{~nm}$ observed for $\mathbf{1}^{\prime}$ is absent for both $\mathbf{1}$ and $\mathbf{2}$ and may thus be safely assigned to the five-coordinate nickel(II). In the case of $\mathbf{1}$ and $\mathbf{2}$, a weak absorption at 621 or $644 \mathrm{~nm}$, respectively, presumably arises from the ${ }^{3} \mathrm{~A}_{2 \mathrm{~g}} \rightarrow{ }^{3} \mathrm{~T}_{1 \mathrm{~g}}(\mathrm{~F})$ transition of the six-coordinate nickel(II), while broad (and overlapping) bands of low intensity around 950 and $1110 \mathrm{~nm}$ are tentatively assigned to the ${ }^{3} \mathrm{~A}_{2 \mathrm{~g}} \rightarrow{ }^{3} \mathrm{~T}_{1 \mathrm{~g}}(\mathrm{P})$ transitions and to spin-forbidden processes of the square-planar low-spin nickel(II).

Complexes $\mathbf{1}$ and $\mathbf{2}$ have been studied by cyclic voltammetry in $\mathrm{MeCN}$ solution in the potential range of +1.8 to $-1.7 \mathrm{~V}$ versus the saturated calomel electrode (SCE). Anodic scans for both $\mathbf{1}$ and $\mathbf{2}$ reveal only ill-defined irreversible processes well above $+1.0 \mathrm{~V}$, thus implying that stable $\mathrm{Ni}^{\mathrm{III}}$ states are inaccessible. In contrast, cathodic responses are more informative. The dinickel(II) complex 1 shows a well-behaved oneelectron-reduction wave at $E_{1 / 2}=-1.05 \mathrm{~V}$ that is assigned to the formation of the $\mathrm{Ni}^{\mathrm{I}} \mathrm{Ni}^{\mathrm{iI}}$ mixed-valent state (Figure 4a). This process is fully reversible $\left[i_{\mathrm{pa}} / i_{\mathrm{pc}}\right.$ close to $1 ; i_{\mathrm{pc}} / v^{1 / 2} \approx$ constant; $\Delta E_{\mathrm{p}}=78 \mathrm{mV}$ with $\Delta E_{\mathrm{p}}\left(\mathrm{Cp}_{2} \mathrm{Fe} / \mathrm{Cp}_{2} \mathrm{Fe}^{+}\right)=71 \mathrm{mV}$ under the same experimental conditions], indicating structural integrity of the bimetallic framework. Further reduction occurs as a broad irreversible wave peaking at around $-1.7 \mathrm{~V}$. Continuing the sweep into this region causes disappearance of the anodic response corresponding to reoxidation of the mixed-valent species upon scan reversal. Considering that nickel(I) prefers low coordination numbers and soft $\pi$-acceptor ligands, we assume the low-spin nickel(II) in $\mathbf{1}$ to be the primary reduction site. This is also corroborated by the fact that no similar cathodic process has previously been observed for any of those dinickel-

(23) Nicholls, D. In Comprehensive Inorganic Chemistry, 1st ed.; Bailar, J. C., Emeleus, H. J., Nyholm, R., Trotman-Dickenson, A. F., Eds.; Pergamon: Oxford, 1973: Vol. 3, p 1152 ff. 

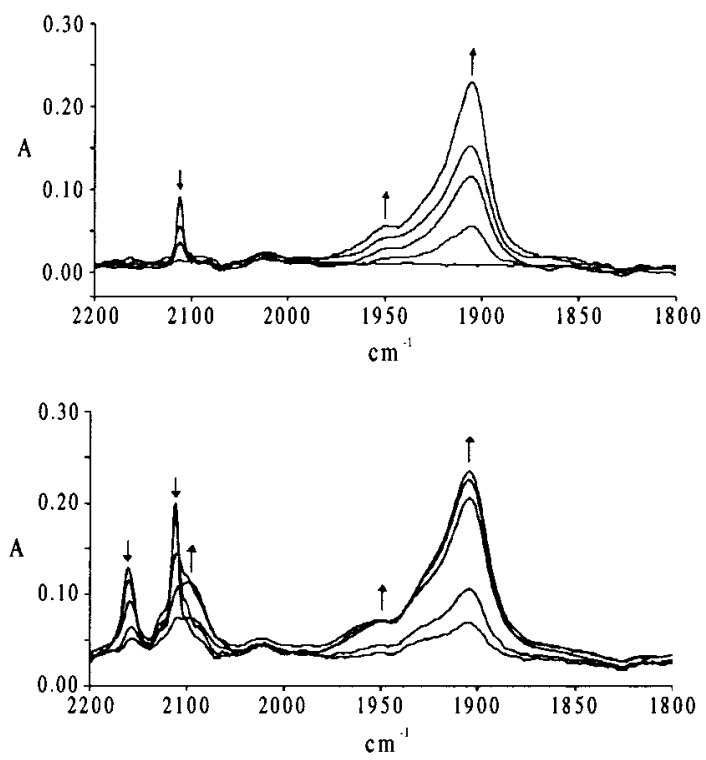

Figure 5. IR spectroscopic changes during gradual reduction of $\mathbf{1}$ (top) and 2 (bottom) in an OTTLE cell.

(II) complexes of HL that feature five- or six-coordinate metal centers within both coordination compartments. ${ }^{14}$

The nonanuclear complex 2 undergoes reduction at $E_{\mathrm{p}}^{\text {red }}=$ $-1.18 \mathrm{~V}$, which is assigned to $\mathrm{Ni}^{\mathrm{I}} \mathrm{Ni}^{\mathrm{II}}$ formation within the pyrazolate-based bimetallic subunits similar to the situation in $\mathbf{1}$ (Figure $4 \mathrm{~b}$ ). However, in the case of $\mathbf{2}$ this redox process is only partially reversible and appears to consist of several oneelectron steps too closely spaced to give separate waves, suggesting little electronic communication between the redox centers within the four outer bimetallic building blocks. At somewhat more negative potentials the first composite wave is followed by another irreversible process centered at $-1.56 \mathrm{~V}$ (scan speed $200 \mathrm{mV} / \mathrm{s}$ ). Upon scan reversal an anodic peak at $-0.34 \mathrm{~V}$ is found while the immediate reoxidation wave due to the first reduction events is strongly diminished. This feature is also detected if the sweep is reversed past the first composite wave, accounting for the only partial chemical reversibility. A continuous sweep between 0 and $-1.38 \mathrm{~V}$ reveals no additional cathodic response due to the peak at $-0.34 \mathrm{~V}$. We assume a square scheme ECEC mechanism for these redox events of $\mathbf{2}$ : the hexacation $\mathbf{2}$ is first reduced to a dicationic species $\mathbf{2}_{\text {red, }}$, which undergoes structural rearrangement forming $\mathbf{2}_{\text {red }}$. This is reoxidized at $-0.34 \mathrm{~V}$, yielding an unstable hexacation $\mathbf{2}^{\prime}$ that quickly reisomerizes to give the starting complex $\mathbf{2}$.

To gain further insight into the changes accompanying electron uptake and to characterize the putative mixed-valent

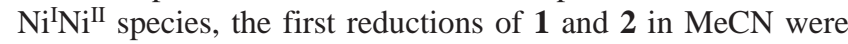
followed by IR and UV/vis spectroscopy in an OTTLE cell (Figures 5 and 6, Tables 4 and 5). Upon gradual electrolysis of $\mathbf{1}$, the intensity of the cyanide stretching vibration at $2112 \mathrm{~cm}^{-1}$ decreases at the expense of a new band at $1905 \mathrm{~cm}^{-1}$ (featuring a shoulder at $1950 \mathrm{~cm}^{-1}$ ). This large shift to lower frequency of around $200 \mathrm{~cm}^{-1}$ reflects the increased $\pi$-back-bonding ability of the reduced $\mathrm{Ni}^{\mathrm{I}}$. Upon reduction of $\mathbf{2}$, the IR stretch assigned to the bent $\mathrm{CN}$ ligands within the peripheral dinickel entities experiences exactly the same shift as was observed for $\mathbf{1}$. The $\mathrm{CN}$ stretch of the linear cyanide bridges that link the outer dinickel subunits to the central tetracyanonickelate is much less affected, shifting from 2160 to $2098 \mathrm{~cm}^{-1}$. Since both different types of $\mathrm{CN}$ ligands are each $\mathrm{N}$-bound to the same high-spin $\mathrm{Ni}^{\mathrm{II}}$, this provides clear evidence that reduction takes place at the peripheral four-coordinate low-spin $\mathrm{Ni}^{\mathrm{II}}$ sites within the
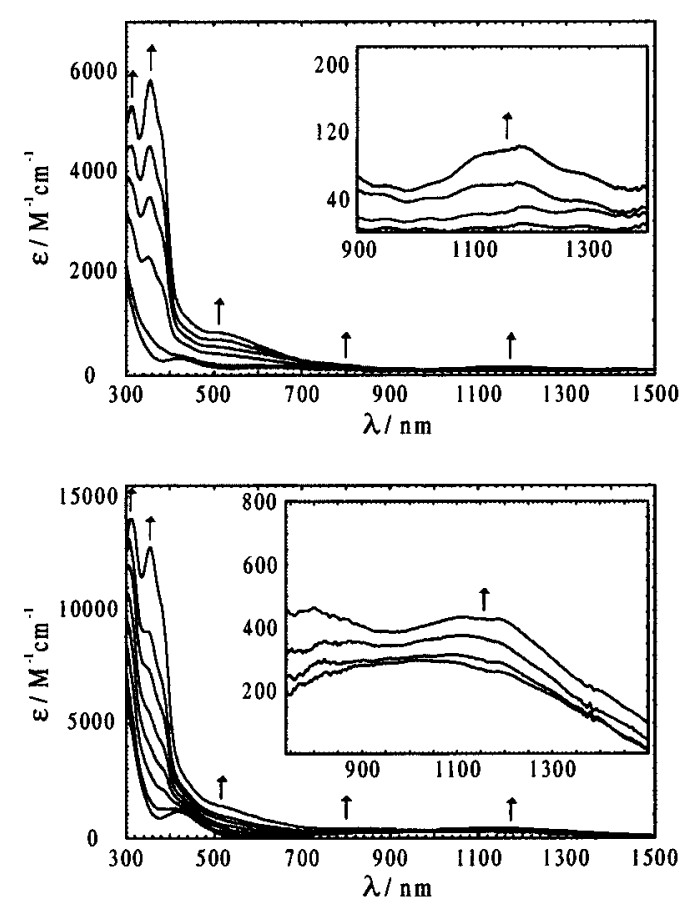

Figure 6. UV/vis spectroscopic changes during gradual reduction of 1 (top) and $\mathbf{2}$ (bottom) in an OTTLE cell.

bimetallic pyrazolate-bridged entities (and likewise at the respective low-spin $\mathrm{Ni}^{\mathrm{II}}$ in $\mathbf{1}$ ). Albeit smaller, the change of the IR stretching frequency of the inner, linear bridging $\mathrm{CN}$ ligands shows that electronic information is transmitted from the outer to the central four-coordinate nickel sites via the six-coordinate $\mathrm{Ni}^{\mathrm{II}}$.

In UV/vis spectroelectrochemistry the reduction of both $\mathbf{1}$ and $\mathbf{2}$ is accompanied by a dramatic increase in absorptivity (Figure 6). Since upon reoxidation of the reduced species the spectrum of the starting material is nearly restored, the absorption coefficients given are quite reliable. The most prominent feature in the spectra of the reduced complexes is a pair of very intense bands around 313 and $355 \mathrm{~cm}^{-1}\left(\log \epsilon>3.6 \mathrm{M}^{-1} \mathrm{~cm}^{-1}\right)$, which we tentatively assign to the $\mathrm{d} \pi \rightarrow \pi^{*}(\mathrm{CN})$ or $\mathrm{d} \pi \rightarrow \pi^{*}$ (pyrazolate) MLCT transitions. In any electronically coupled, mixed-valent system one expects metal-to-metal intervalence charge-transfer (MMCT-IVCT) absorptions. There is ample literature precedent that bridging cyanide ligands allow for such electronic communication even in unsymmetrical dinuclear complexes. ${ }^{24}$ Due to the inherently different electronic properties of the low- and high-spin nickel sites the energy of the IVCT transition may be considerably higher than in symmetrical counterparts. Here, the most likely candidate for the IVCT band is the rather weak absorption at $505 \mathrm{~nm}$ for $\mathbf{1}\left(\epsilon \approx 740 \mathrm{M}^{-1}\right.$ $\mathrm{cm}^{-1}$ ) and at $520 \mathrm{~nm}$ for $\mathbf{2}$, both being located at the low-energy portion of the much more intense MLCT bands. Spectral deconvolution gives a half-bandwidth $\Delta v_{1 / 2}$ of around 7100 $\mathrm{cm}^{-1}$ for $\mathbf{1}$, in good agreement with the value estimated from Hush's formula $\left[\Delta v_{1 / 2}=\left(2310 v_{\max }\right)^{1 / 2} \approx 6800 \mathrm{~cm}^{-1}\right]$ describing only moderately coupled class II mixed-valent systems. Additional low-intensity absorptions of the reduced species at around $1150 \mathrm{~nm}$ (see insets in Figure 6) clearly have much

(24) (a) Zhu, N.; Vahrenkamp, H. J. Organomet. Chem. 1994, 472, C5C7. (b) Zhu, N.; Vahrenkamp, H. Chem. Ber./Recl. 1997, 130, 12411252. (c) Geiss, A.; Kolm, M. J.; Janiak, C.; Vahrenkamp, H. Inorg. Chem. 2000, 39, 4037-4043.

(25) Krejcik, M.; Daniek, M.; Hartl, F. J. Electroanal. Chem. 1991, 317, 179-187. 
smaller bandwidths and absorptivities and presumably represent $\mathrm{d}-\mathrm{d}$ type transitions.

\section{Conclusions}

A dinickel complex and a related nonanuclear array comprising four such bimetallic entities have been prepared and structurally characterized, both incorporating extremely bent cyanide bridges between two different six- and four-coordinated $\mathrm{Ni}^{\mathrm{II}}$ sites. The two metal ions within the dinickel building blocks are preorganized at a well-defined distance by means of a compartmental ligand matrix. The mixed-spin dinuclear complex 1 features an accessible coordination site at the high-spin nickel(II) ion, which allowed us to assemble the unique system 2 of higher nuclearity by linking four bimetallic building blocks via a central cyanometalate. Both $\mathbf{1}$ and $\mathbf{2}$ can be reduced electrochemically to give mixed-valent $\mathrm{Ni}^{\mathrm{I}} \mathrm{Ni}^{\mathrm{II}}$ species. The structural features observed for $\mathbf{1}$ and for the starlike nonanuclear complex 2 demonstrate the ability of two cooperating metal ions to enforce unusual coordination modes by their synergetic action.
The unusually bent cyanide binding at the pyrazolate scaffold is obviously imposed by the dinuclear pincer effect, i.e., by the seizing of the small coligand within a highly preorganized bimetallic pocket. Such phenomena may also be encountered for the highly organized and constrained substrate binding within the protein active site pockets of natural metalloenzymes.

Acknowledgment. We are grateful to Prof. Dr. G. Huttner and Prof. Dr. W. Kaim for their generous support and their interest in our work. T. Jannack and Dr. M. Gross are sincerely thanked for collecting the mass spectra. Funding by the Deutsche Forschungsgemeinschaft (Heisenberg-Stipendium to F.M.), the VW-Stiftung (R.F.W.), and the Fonds der Chemischen Industrie is gratefully acknowledged.

Supporting Information Available: Crystallographic data, in CIF format, for $\mathbf{1}$ and $\mathbf{2}$. A cyclic voltammogram and IR spectra for $\mathbf{1}$ and 2. This material is available free of charge via the Internet at http://pubs.acs.org.

IC010249X 